Article

\title{
Cloning and Characterization of a Flavonoid 3'-Hydroxylase Gene from Tea Plant (Camellia sinensis)
}

\author{
Tian-Shan Zhou ${ }^{1}$, Rui Zhou ${ }^{2}$, You-Ben Yu ${ }^{1}$, Yao Xiao ${ }^{1}$, Dong-Hua Li ${ }^{1}$, Bin Xiao ${ }^{1}$, Oliver Yu ${ }^{2, *}$ \\ and Ya-Jun Yang ${ }^{3, *}$ \\ 1 Horticulture, Northwest A\&F University, 3 Taicheng Road, Yangling 712100, China; \\ zhoutianshan@nwsuaf.edu.cn (T.-S.Z.); yyben@163.com (Y.-B.Y.); xiaoyao1583@gmail.com (Y.X.); \\ lidhua29@163.com (D.-H.L.); xiaobin@nwsuaf.edu.cn (B.X.) \\ 2 Conagen Inc., 15 DeAngelo Dr., Bedford, MA 01730, USA; rui.zhou@conagen-inc.com \\ 3 Tea Research Institute, Chinese Academy of Agricultural Sciences, 9 Meiling South Road, \\ Hangzhou 310008, China \\ * Correspondence: Oliver.yu@conagen-inc.com (O.Y.); yjyang@mail.tricaas.com (Y.-J.Y.); \\ Tel.: +1-781-271-1588 (O.Y.); +86-571-8665-3162 (Y.-J.Y.)
}

Academic Editor: Marcello Iriti

Received: 9 December 2015; Accepted: 15 February 2016; Published: 22 February 2016

\begin{abstract}
Tea leaves contain abundant flavan-3-ols, which include dihydroxylated and trihydroxylated catechins. Flavonoid $3^{\prime}$-hydroxylase $\left(\mathrm{F}^{\prime}{ }^{\prime} \mathrm{H}\right.$ : EC 1.14.13.21) is one of the enzymes in the establishment of the hydroxylation pattern. A gene encoding $\mathrm{F}^{\prime} \mathrm{H}$, designated as $C s F 3^{\prime} H$, was isolated from Camellia sinensis with a homology-based cloning technique and deposited in the GenBank (GenBank ID: KT180309). Bioinformatic analysis revealed that $C s F 3^{\prime} H$ was highly homologous with the characterized $\mathrm{F}^{\prime} \mathrm{Hs}$ from other plant species. Four conserved cytochrome P450-featured motifs and three $\mathrm{F}^{\prime} \mathrm{H}$-specific conserved motifs were discovered in the protein sequence of $\mathrm{CsF}^{\prime} \mathrm{H}$. Enzymatic analysis of the heterologously expressed $\mathrm{CsF}^{\prime} \mathrm{H}$ in yeast demonstrated that tea $\mathrm{F}^{\prime} \mathrm{H}$ catalyzed the $3^{\prime}$-hydroxylation of naringenin, dihydrokaempferol and kaempferol. Apparent $K_{\mathrm{m}}$ values for these substrates were $17.08,143.64$ and $68.06 \mu \mathrm{M}$, and their apparent $V_{\max }$ values were $0.98,0.19$ and $0.44 \mathrm{pM} \cdot \mathrm{min}^{-1}$, respectively. Transcription level of $C s F 3^{\prime} H$ in the new shoots, during tea seed germination was measured, along with that of other key genes for flavonoid biosynthesis using real-time PCR technique. The changes in $3^{\prime}, 4^{\prime}$-flavan-3-ols, $3^{\prime}, 4^{\prime}, 5^{\prime}$-flavan-3-ols and flavan-3-ols, were consistent with the expression level of $\mathrm{CsF}^{\prime} \mathrm{H}$ and other related genes in the leaves. In the study of nitrogen supply for the tea plant growth, our results showed the expression level of $\mathrm{CsF}^{\prime} H$ and all other tested genes increased in response to nitrogen depletion after 12 days of treatment, in agreement with a corresponding increase in $3^{\prime}, 4^{\prime}$-catechins, $3^{\prime}, 4^{\prime}, 5^{\prime}$-catechins and flavan 3-ols content in the leaves. All these results suggest the importance of $C_{S F} 3^{\prime} H$ in the biosynthesis of $3^{\prime}, 4^{\prime}$-catechins, $3^{\prime}, 4^{\prime}, 5^{\prime}$-catechins and flavan 3-ols in tea leaves.
\end{abstract}

Keywords: flavonoid 3'-hydroxylase; heterologous expression; flavan 3-ols; nitrogen depletion; Camellia sinensis

\section{Introduction}

Tea (Camellia sinensis) is an important economic crop native to southwestern China [1]. Tea leaves can be processed into the most widely consumed beverage. Increasing evidence suggests that tea extracts produce beneficial health effects, such as anticancer [2], anti-vascular disease [3], anti-bacterial [4], anti-inflammation [5], and anti-allergic [6] activities. The leaves of tea plants have large amounts of flavonoids, which include flavones, flavanones, flavonols, flavan 3-ols (as known as catechins), and 
anthocyanidins [7]. The major flavonoid compounds in tea are flavan 3-ols, which possess strong radical scavenging and antioxidant effects [8]. Flavan 3-ols are synthesized through the phenylpropanoid and flavonoid pathways [9-12], illustrated in Figure 1. The entry point for the biosynthesis of flavan 3 -ol is the formation of chalcone with the catalyzation of chalcone synthase (CHS). The other enzymes involved in this biosynthetic pathway include chalcone isomerase (CHI), flavanone 3-hydroxylase (F3H), dihydroflavonol 4-reductase (DFR), leucocyanidin reductase (LAR), anthocyanidin synthase (ANS), anthocyanidin reductase (ANR), and flavan 3-ol gallate synthase (FGS, no report) [10,11].

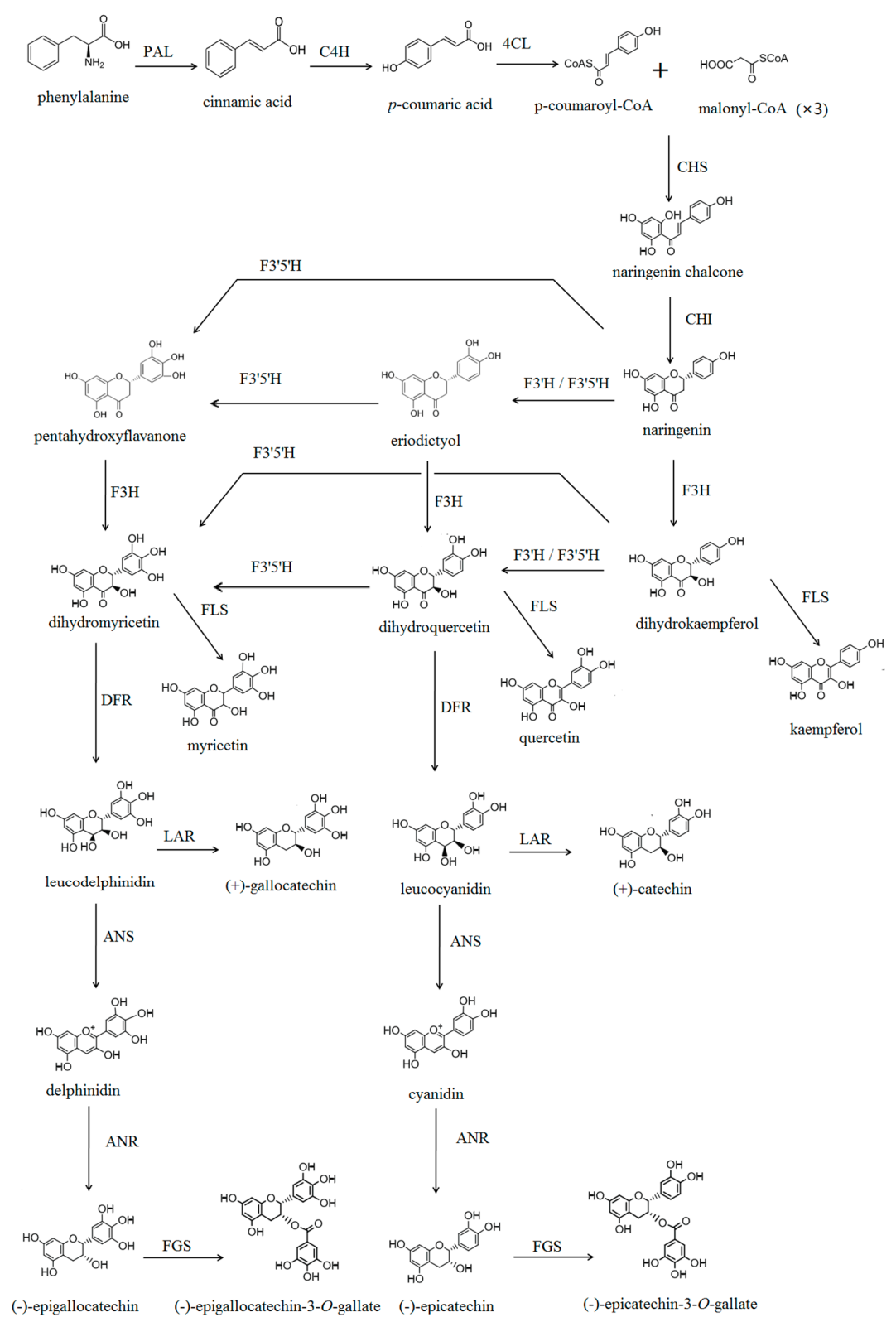

Figure 1. Suggested biosynthetic pathways of flavan 3-ols in Camellia sinensis leaves. Abbreviations of enzymes are as follows: PAL, phenylalanine ammonia-lyase (EC 4.3.1.24); $\mathrm{C} 4 \mathrm{H}$, cinnamic acid 4-hydroxylase (EC 1.14.13.11); 4CL, 4-coumarate-CoA ligase (EC 6.2.1.12); CHS, chalcone synthase (EC 2.3.1.74); CHI, chalcone isomerase (EC 5.5.1.6); $\mathrm{F3H}$, flavanone 3-hydroxylase (EC 1.14.11.9); F3' $5^{\prime} \mathrm{H}$, flavonoid $3^{\prime}, 5^{\prime}$-hydroxylase (EC 1.14.13.88); F3' $\mathrm{H}$, flavonoid $3^{\prime}$-hydroxylase (EC 1.14.13.21); FLS, flavonol synthase (EC 1.14.11.23); DFR, dihydroflavanol 4-reductase (EC 1.1.1.219); ANS, anthocyanidin synthase (EC 1.14.11.19); ANR, anthocyanidin reductase (EC 1.3.1.77); LAR, leucocyanidin reductase (EC 1.17.1.3); FGS, flavan 3-ol gallate synthase (EC number not assigned). 
Major flavan 3-ols in tea include (+)-catechin, (-)-epicatechin, (-)-epicatechin gallate, (-)-epigallocatechin (+)-gallocatechin and (-)-epigallocatechin gallate. Based on the hydroxylation position in the B-ring, catechins can be categorized in several subclasses, including $3^{\prime}, 4^{\prime}$-dihydroxylated catechins ( $3^{\prime}, 4^{\prime}$-flavan 3 -ols) and $3^{\prime}, 4^{\prime}, 5^{\prime}$-trihydroxylated catechins $\left(3^{\prime}, 4^{\prime}, 5^{\prime}\right.$-flavan 3 -ols). The ratio of dihydroxylated to trihydroxylated catechins (RDTC) in tea was used as an indicator of tea quality in the breeding programs [13-15]. The hydroxylation pattern of the B-ring of flavonoids was found to be determined by F3' $\mathrm{H}$ and flavonoid $3^{\prime}, 5^{\prime}$-hydroxylase $\left(\mathrm{F}^{\prime} 5^{\prime} \mathrm{H}\right)$, which catalyze the hydroxylation at the $3^{\prime}$ - or the $3^{\prime}$-and $5^{\prime}$-position of flavonoids, respectively $[12,16-18] . \mathrm{F}^{\prime} \mathrm{H}$ and $\mathrm{F} 3^{\prime} 5^{\prime} \mathrm{H}$ are classified to the subfamilies of CYP75B and CYP75A, respectively, in the superfamily of cytochrome P450-dependent monooxygenases [19]. In flavonoid biosynthesis, $\mathrm{F}^{\prime}{ }^{\prime} \mathrm{H}$ hydroxylates the B-ring of naringenin and dihydrokaempferol at the $3^{\prime}$-position to form eriodictyol and dihydroquercetin, respectively, the two important intermediates for the biosynthesis of $3^{\prime}, 4^{\prime}$-dihydroxyl flavonoid end-products formed in plants. Even though tea $F 3^{\prime} H$ s were reported before [20], the function has not been fully characterized yet. The enzymatic characterization of $\mathrm{CsF}^{\prime} \mathrm{H}$ is essential for us to understand the role of $\mathrm{CsF}^{\prime} \mathrm{H}$ in the flavonoid biosynthetic system (Figure 1). Furthermore, the content of flavonoids in plant was influenced by environmental conditions such as nitrogen supply [21,22]. Study of the expression of $F 3^{\prime} H$ and other genes related to flavonoid under limited nitrogen condition would help the functional characterization in vivo.

With a goal to functionally characterize $\mathrm{CsF}^{\prime} \mathrm{H}$ in vitro and in vivo, we isolated a $\mathrm{CsF}^{\prime} \mathrm{H}$ gene from tea by homologous cloning. Enzymatic analysis of the heterologous expressed $C s F 3^{\prime} H$ in yeast revealed that naringenin is the optimal substrate for this enzyme. The expression pattern of $C s F 3^{\prime} H$ correlated positively with $3^{\prime}, 4^{\prime}$-flavan 3-ols, $3^{\prime}, 4^{\prime}, 5^{\prime}$-flavan 3-ols and flavan 3-ols accumulation pattern in the tea seedling during the growth period. The expression level of $\mathrm{CsF}^{\prime} \mathrm{H}$ also responded to nitrogen supplication, with the expression level of $C s F 3^{\prime} H$ increased significantly after nitrogen depletion, resulting in an increased content of $3^{\prime}, 4^{\prime}$-catechins in the leaves.

\section{Results and Discussion}

\subsection{Cloning and Sequence Analysis of CsF3'H Gene}

A fragment of $1056 \mathrm{bp}$ was obtained from PCR amplification of the partial target cDNA with degenerated primers. Subsequent $5^{\prime}$-RACE and $3^{\prime}$-RACE yielded an $1120 \mathrm{bp} 5^{\prime}$-end and an $1447 \mathrm{bp}$ $3^{\prime}$-end cDNA fragments, respectively. A full length cDNA sequence of flavonoid $3^{\prime}$-hydroxylase was then obtained by using the SeqMan program in DNAStar 7.1 (DNASTAR Inc., Madison, AL, USA). The full transcript has 1706 nucleotideswith a $5^{\prime}$-untranslated region (UTR) of $26 \mathrm{bp}$, an open reading frame (ORF) of $1557 \mathrm{bp}$ and a 3'-UTR of $124 \mathrm{bp}$ (Genbank ID: KT180309). CsF3'H was predicted to encode a protein with 518 amino acids, a theoretical molecular weight of $57.07 \mathrm{kDa}$ and a calculated isoelectric point of 6.82 .

Four cytochrome $\mathrm{P} 450$-specific conserved motifs and three $\mathrm{F} 3^{\prime} \mathrm{H}$-specific conserved motifs were found in $\mathrm{CsF}^{\prime} \mathrm{H}$ amino acid sequence using the Conserved Domain program at the NCBI website (showed in Figure 2). The proline-rich "hinge" region $\left(\mathrm{P}_{36} \mathrm{PGPTPWP}_{43}\right)$ is supposed to be required for optimal orientation of P450 enzymes [23-25]. The heme domain $\left(\mathrm{F}_{448} \mathrm{GAGRRICAG}_{457}\right)$ is responsible for the enzyme to bind carbon monoxide [19]. $\mathrm{CsF}^{\prime} \mathrm{H}$ bears the motif $\mathrm{A}_{312} \mathrm{GTDTS}_{315}$, forming a binding pocket for oxygen molecule, which is required for its catalytic activity [26]. An $E_{369}-R_{371}-R_{411}$ triad forming the pocket locking motif for the stabilization of the core structure [27], is also present in $\mathrm{CsF}^{\prime} \mathrm{H}$. In addition, two F3'H-specific motifs "VVVAAS" and "GGEK" [28] have high similarity counterparts at $\mathrm{V}_{79} \mathrm{VVAAS}_{84}$ and $\mathrm{G}_{430} \mathrm{GEK}_{433}$ in $\mathrm{CsF}^{\prime} \mathrm{H}$, respectively. But the third $\mathrm{F}^{\prime} \mathrm{H}$-specific motifs VDVKG [28] was present at $\mathrm{A}_{436} \mathrm{DVRG}_{440}$ of $\mathrm{CsF3}^{\prime} \mathrm{H}$. 


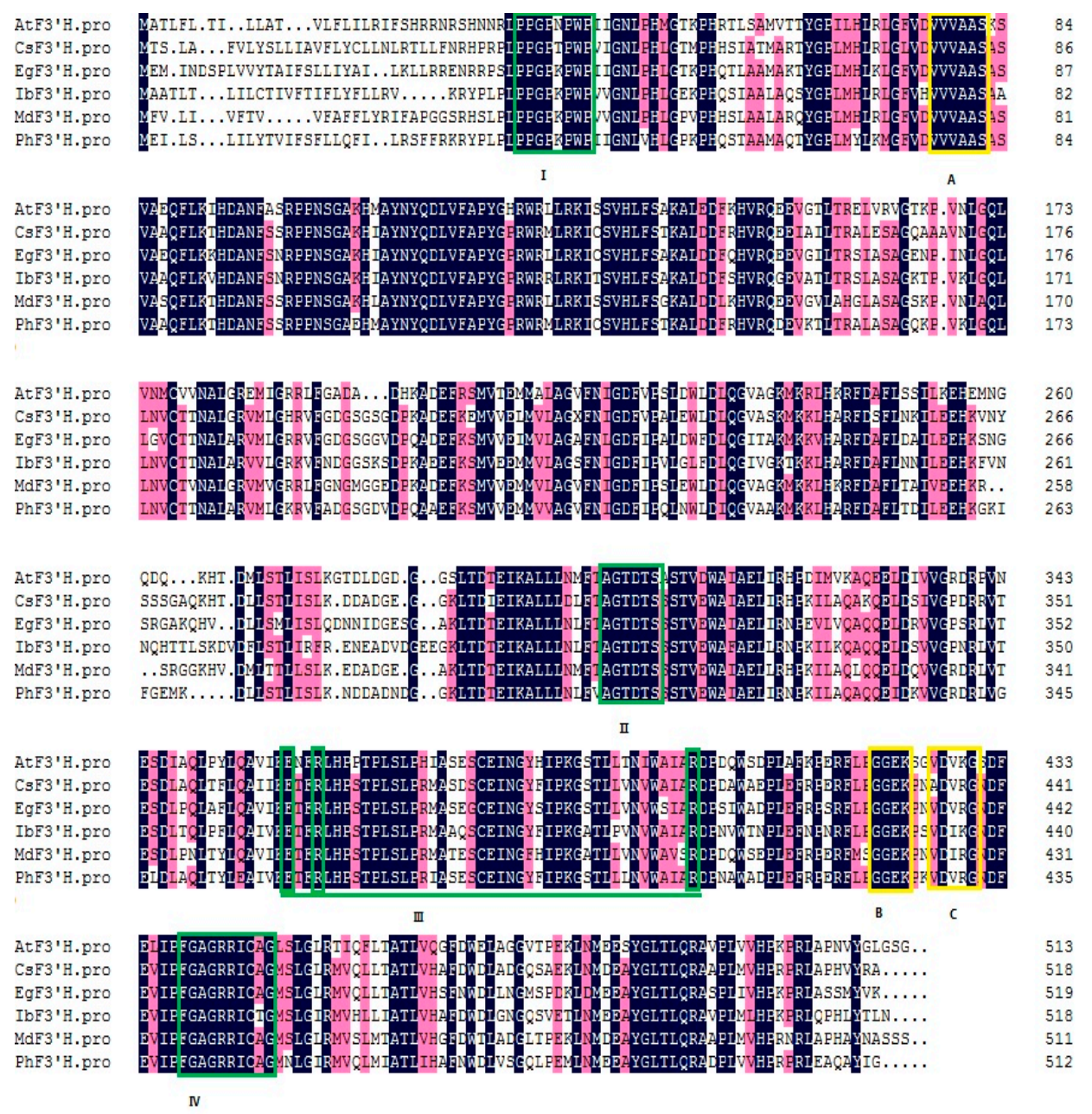

Figure 2. Multiple sequence alignment of the $\mathrm{CsF}^{\prime} \mathrm{H}$ protein and five flavonoid $3^{\prime}$-hydroxylases $\left(\mathrm{F}^{\prime} \mathrm{Hs}\right)$. Besides $\mathrm{CsF}^{\prime} \mathrm{H}$, other amino acid sequences included in this alignment were $\mathrm{AtF}^{\prime} \mathrm{H}$ (Genbank ID: CAB62611.1); PhF3'H (Genbank ID: AAD56282.1); EgF3'H (Genbank ID: BAP94456.1); $\mathrm{MdF3}^{\prime} \mathrm{H}$ (Genbank ID: ACR14867.1) and IbF3'H (Genbank ID: AEH42499.1). At, Arabidopsis thaliana; $\mathrm{Ph}$, Petunia hybrida; Eg, Eustoma grandiflorum; Md, Malus $\times$ domestica; Ib, Ipomoea batatas. Dark-blue shading and pinkish shading reflect $100 \%$ and $75 \%$ amino acid residues conservation, respectively. The P450-featured conserved motif, including the proline-rich "hinge" region (I), oxygen binding pocket motif (II), E-R-R motif (III) and heme-binding domain (IV) are boxed in green. Three F3' $\mathrm{H}$-specific conserved motifs are boxed in yellow (marked A, B and C).

Five well characterized $\mathrm{F}^{\prime} \mathrm{H}$ s from other plant species, $\mathrm{MdF3}^{\prime} \mathrm{H}$ from Malus $\times$ domestica (GenBank ID: ACR14867.1) [29], PhF3'H from Petunia hybrida (GenBank ID: AAD56282.1) [17], EgF3'H from Eustoma grandiflorum (GenBank ID: BAP94456.1) [30], IbF3 ${ }^{\prime} \mathrm{H}$ from Ipomoea batatas (GenBank ID: AEH42499.1) [31] and AtF3'H from Arabidopsis thaliana (GenBank ID: CAB62611.1) [18] were selected for sequence comparison. Multiple amino acid sequence alignment revealed high homology to these five $\mathrm{F}^{\prime} \mathrm{H}$ sequences. $\mathrm{CsF}^{\prime} \mathrm{H}$ showed $76 \%, 75 \%, 73 \%, 67 \%$ and $66 \%$ identities with them, respectively (Figure 2).

A phylogenetic tree (Figure 3) was generated with several $\mathrm{F}^{\prime}{ }^{\prime} \mathrm{H}$ protein sequences from several plant species, including the reported tea F3 ${ }^{\prime} \mathrm{Hs}[20]$ and $\mathrm{F}^{\prime} 5^{\prime} \mathrm{Hs}$. The tree clearly showed that $\mathrm{F}^{\prime} \mathrm{Hs}$ and $\mathrm{F}^{\prime} 5^{\prime} \mathrm{Hs}$ were clustered in the $\mathrm{CYP75B}$ and $\mathrm{CYP75A}$ clades, respectively. $\mathrm{CsF}^{\prime} \mathrm{H}$ was grouped into the CYP75B subfamilies, and tightly related to the $\mathrm{F}^{\prime}{ }^{\prime} \mathrm{H}$ from Camellia nitidissima. In addition, $\mathrm{CsF}^{\prime} \mathrm{H}$ and the $\mathrm{CsF}^{\prime} \mathrm{H} 2$ (GenBank ID: AKM12329) [20] were clustered together. But two other $\mathrm{CsF}^{\prime} \mathrm{Hs}$ 
(CsF3'H1, GenBank ID: AKJ86992 and CsF3'H3, GenBank ID: AKM12330) [20] were clustered neither in CYP75B nor in CYP75A.

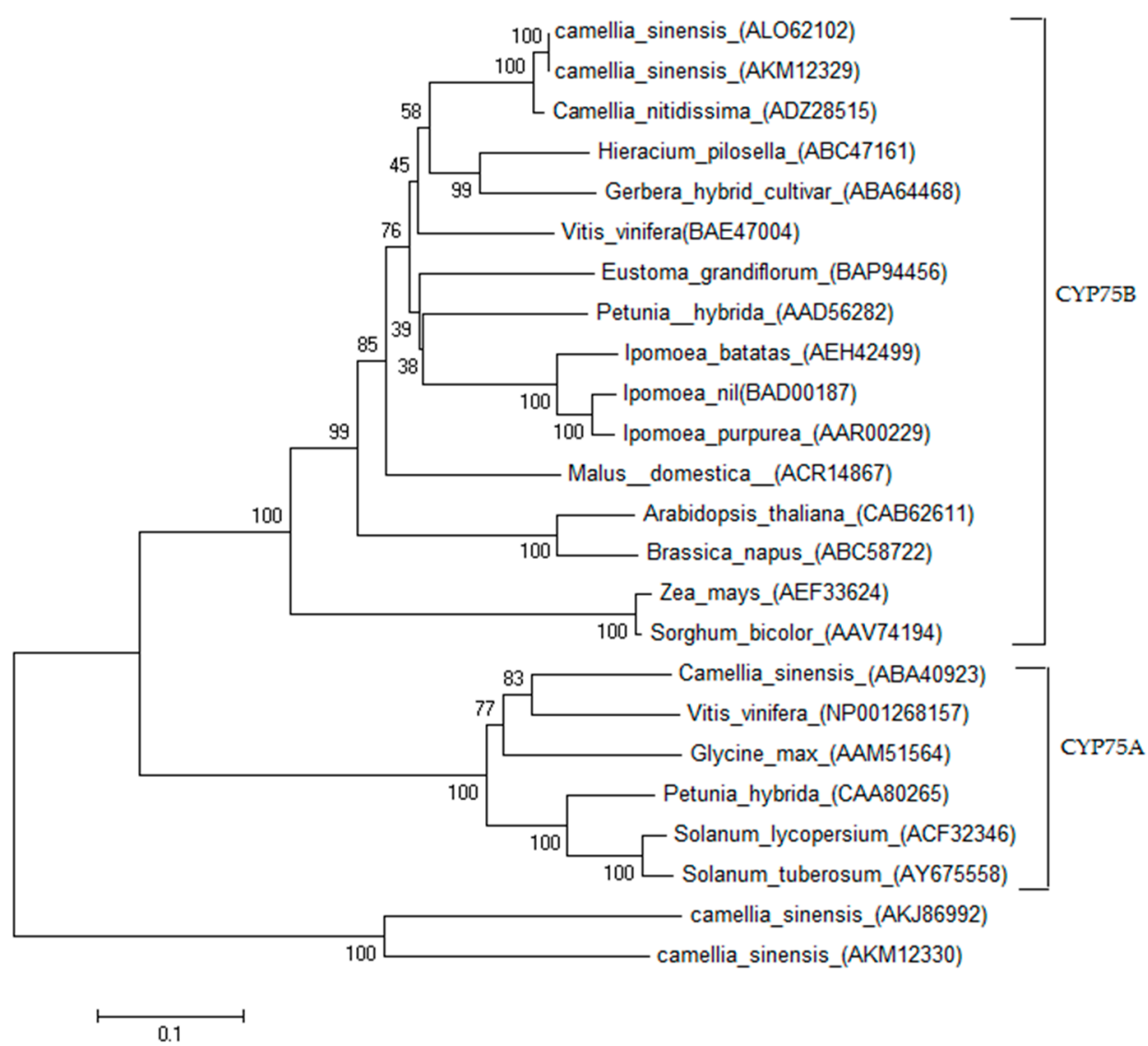

Figure 3. Phylogenetic analysis of $\mathrm{CsF}^{\prime} \mathrm{H}$ protein and the proteins of $\mathrm{F}^{\prime} \mathrm{H}$ and $\mathrm{F}^{\prime} 5^{\prime} \mathrm{H}$ from other species. The phylogenetic tree was constructed from the ClustalW alignment using the neighbour joining method by the MEGA 6.0 program. Branches were labelled with the protein names and GenBank accession numbers. The scale bar represents 0.1 substitutions per site, and the numbers next to the nodes were bootstrap values from 1000 replicates.

\subsection{Substrate Specificity of $\mathrm{CsF}^{\prime} \mathrm{H}$}

The yeast strain Saccharomyces cerevisiae WAT11, originally engineered to over-express a P450 reductase from Arabidopsis thaliana [32], was identified as a good heterologous host for plant P450 protein expression $[12,16,33]$. In the present study a vector of pYES-DEST52-CsF3' $H$ was introduced into WAT11 and an empty pYES-DEST52 vector was transformed into WAT11 as a control. According to some previous findings $[17,18,34,35]$, naringenin, dihydrokaempferol and kaempferol were chosen to assess the substrate specificity (Figure 4). WAT11 cells transformed with pYES-DEST52-CsF3' $H$ vector catalyzed the hydroxylation at B-ring 3'-position of naringenin, dihydrokaempferol and kaempferol to eriodictyol, dihydroquercetin and quercetin, respectively, which indicates a broad substrate specificity of $\mathrm{CsF}^{\prime} \mathrm{H}$. In a recent report [36] leucopelargonidin was demonstrated to be also a substrate for $\mathrm{F}^{\prime} \mathrm{H}$. Due to the limited availability of the substrate, this compound was not covered in the present study.

Microsomal fractions from WAT11 cells harboring pYES-DEST52-CsF3 ${ }^{\prime} H$ were prepared and tested for NADPH-dependent $3^{\prime}$-hydroxylation of flavonoids using naringenin, dihydrokaempferol and kaempferol as substrates. The control microsomes did not show any activity. The apparent $K_{\mathrm{m}}$ values of $\mathrm{F}^{\prime} \mathrm{H}$ for these flavonoids were measured to be $17.08,143.64$ and $68.06 \mu \mathrm{M}$, and their apparent $V_{\max }$ values were $0.98,0.19$ and $0.44 \mathrm{pM} \cdot \mathrm{min}^{-1}$, respectively. (Table 1 and Figure S1). The $k_{\text {cat }} / K_{\mathrm{m}}$ values indicated that naringenin is the preferred substrate for $\mathrm{CsF}^{\prime} \mathrm{H}$ enzyme (Table 1). 

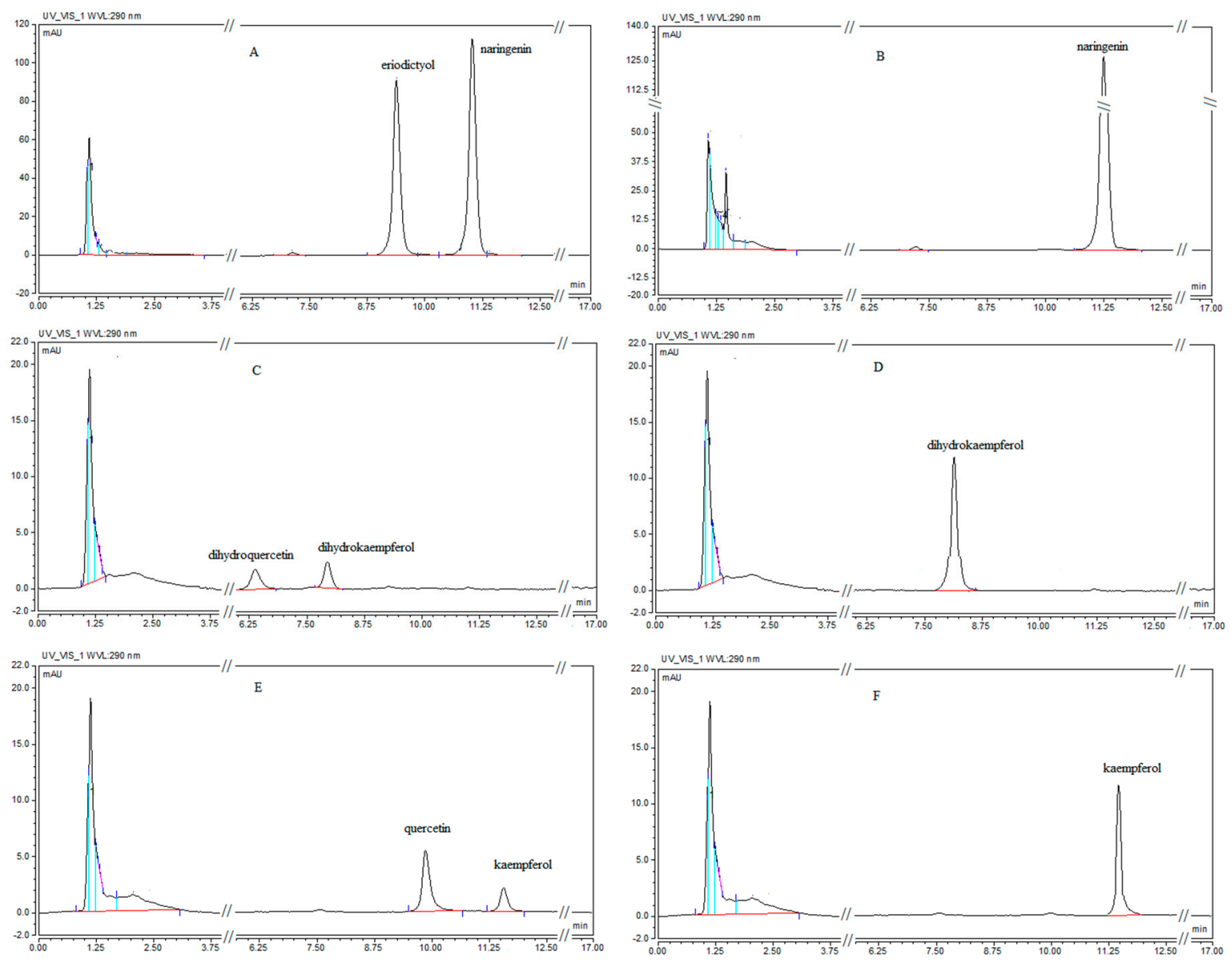

Figure 4. HPLC chromatograms of products from yeast cells with naringenin, dihydrokaempferol and kaempferol as substrates. HPLC chromatograms of products from pYES-dest52-CsF3' $H$ with naringenin (A), dihydrokaempferol (C) and kaempferol (E) as substrates; HPLC chromatograms of products from the control with naringenin (B), dihydrokaempferol (D) and kaempferol (F) as substrates.

Table 1. Steady-state kinetic parameters for $\mathrm{CsF}^{\prime} \mathrm{H}$ in microsomes.

\begin{tabular}{cccc}
\hline Substrate & Naringenin & Dihydrokaempferol & Kaempferol \\
\hline$K_{\mathrm{m}}(\mu \mathrm{M})$ & $17.08 \pm 0.46$ & $143.64 \pm 0.69$ & $68.06 \pm 0.43$ \\
$V_{\max }\left(\mathrm{pM} \cdot \mathrm{min}^{-1}\right)$ & $0.98 \pm 0.01$ & $0.19 \pm 0.01$ & $0.44 \pm 0.01$ \\
$k_{\text {cat }}\left(\mathrm{pM} \cdot \mathrm{min}^{-1} \cdot \mathrm{mg}^{-1} \cdot \mathrm{microsome}^{-1}\right)$ & $49.09 \pm 0.21$ & $9.86 \pm 0.13$ & $21.88 \pm 0.35$ \\
$k_{\text {cat }} / K_{\mathrm{m}}\left(\times 10^{-3} \mathrm{~min}^{-1} \cdot \mathrm{mg}^{-1} \cdot\right.$ microsome $)$ & $2.88 \pm 0.07$ & $0.07 \pm 0.01$ & $0.32 \pm 0.01$ \\
\hline \multicolumn{2}{c}{ The data represent the mean + SD from three independent measurements. }
\end{tabular}

The data represent the mean \pm SD from three independent measurements.

It should be noted, however, that the substrates we used are racemic mixtures. F3' $\mathrm{H}$ was shown to be highly stereospecific for the $2 S$-enantiomer $[37,38]$. Currently we have no idea whether the presence of $2 R$-enantionmer disturbs the enzymatic reaction or not. As the enantiomeric pure flavonoid compounds were not commercially available, and the facilities required for purifying them were not available either, we cannot exclude the possibility that stereochemistry of the substrates (naringenin and dihydrokaempferol) used in our present study might influence the above results.

\subsection{Gene Expression and Flavan 3-ol Accumulation in Tea Seed Germination}

The new shoots (including shoot apex and developing leaves) were collected at 20, 30, 40 and 50 days after tea seed germination respectively. As shown in Figure 5, the developmental process of 
tea seedling was divided into four stages, during which the new tea shoots gradually changed from one bud (S1) to one bud with three leaves (S4).

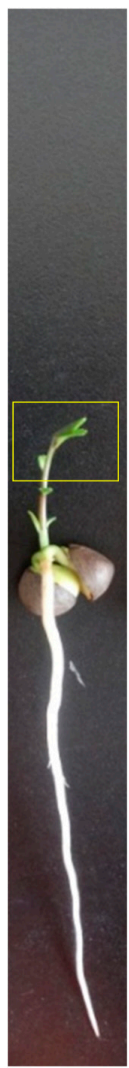

S1

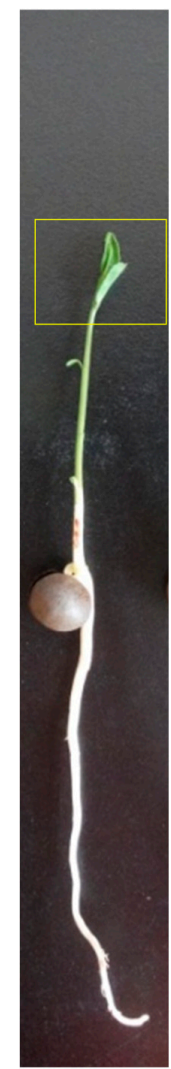

S2

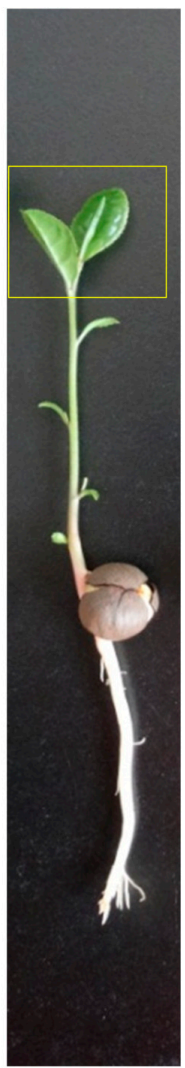

S3

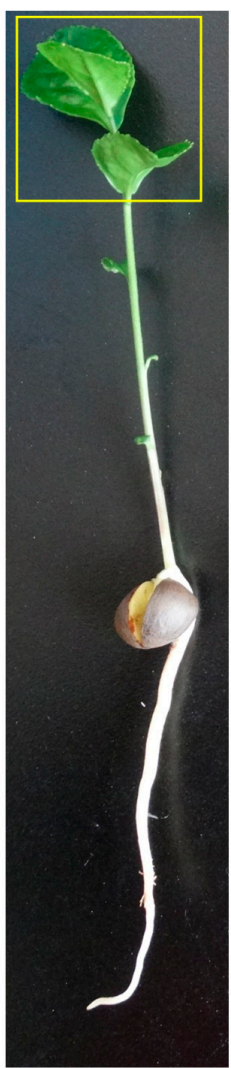

S4

Figure 5. Tea seedlings at different developmental stages. S1, S2, S3 and S4 indicate the tea seedling at 20, 30, 40 and $50 \mathrm{~d}$ after germination respectively. Sampling sites were boxed in yellow.

\subsubsection{Gene Expression}

We compared the expression profiles of $C s F 3^{\prime} H$ and other flavan 3-ol biosynthetic genes (PAL, CHS, CHI, F3H, F3' $5^{\prime} H$, DFR, LAR, ANS, ANR1 and ANR2) by quantitative (q)RT-PCR. The changes in the expression levels for flavan 3-ol biosynthesis related genes are shown in Figure 6. Interestingly, $\mathrm{CsF}^{\prime} \mathrm{H}$ and other flavan 3-ol biosynthetic genes showed similar variation pattern during the plant growth. Their expression level gradually increased to the maximum by S3 and decreased rapidly in S4. But the increment varied among of them. Compared to S1, the highest expression level of $P A L, C H S$, CHI, LAR, F $3^{\prime} 5^{\prime} H$, ANS and ANR1 recorded at S3 were 22.51-, 21.85-, 14.6-, 15.64-, 25.82-, 16.85- and 10.66-fold respectively. However, the expression levels of $D F R, F 3 H, F 3^{\prime} H$ and $A N R 1$ were high in S3, only $6.54-, 3.21-, 4.12$ - and 6.29-fold compare to $S 1$ respectively.

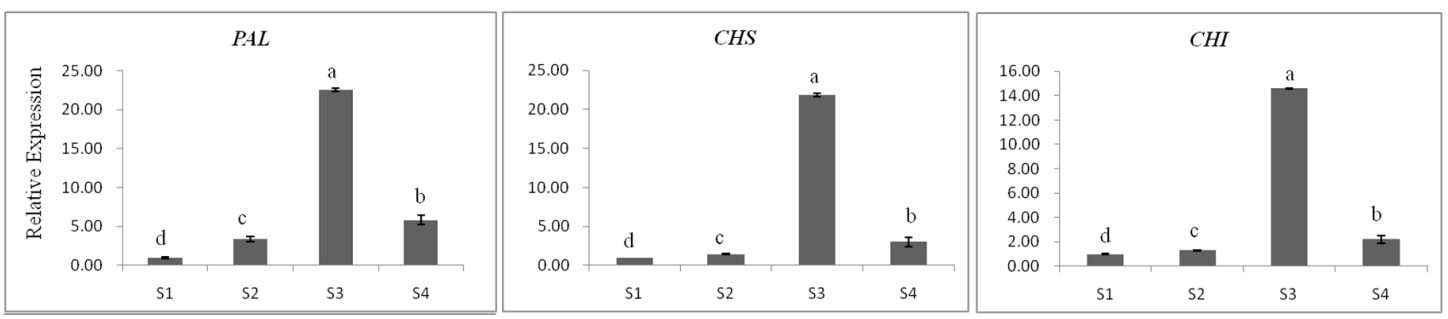

Figure 6. Cont. 


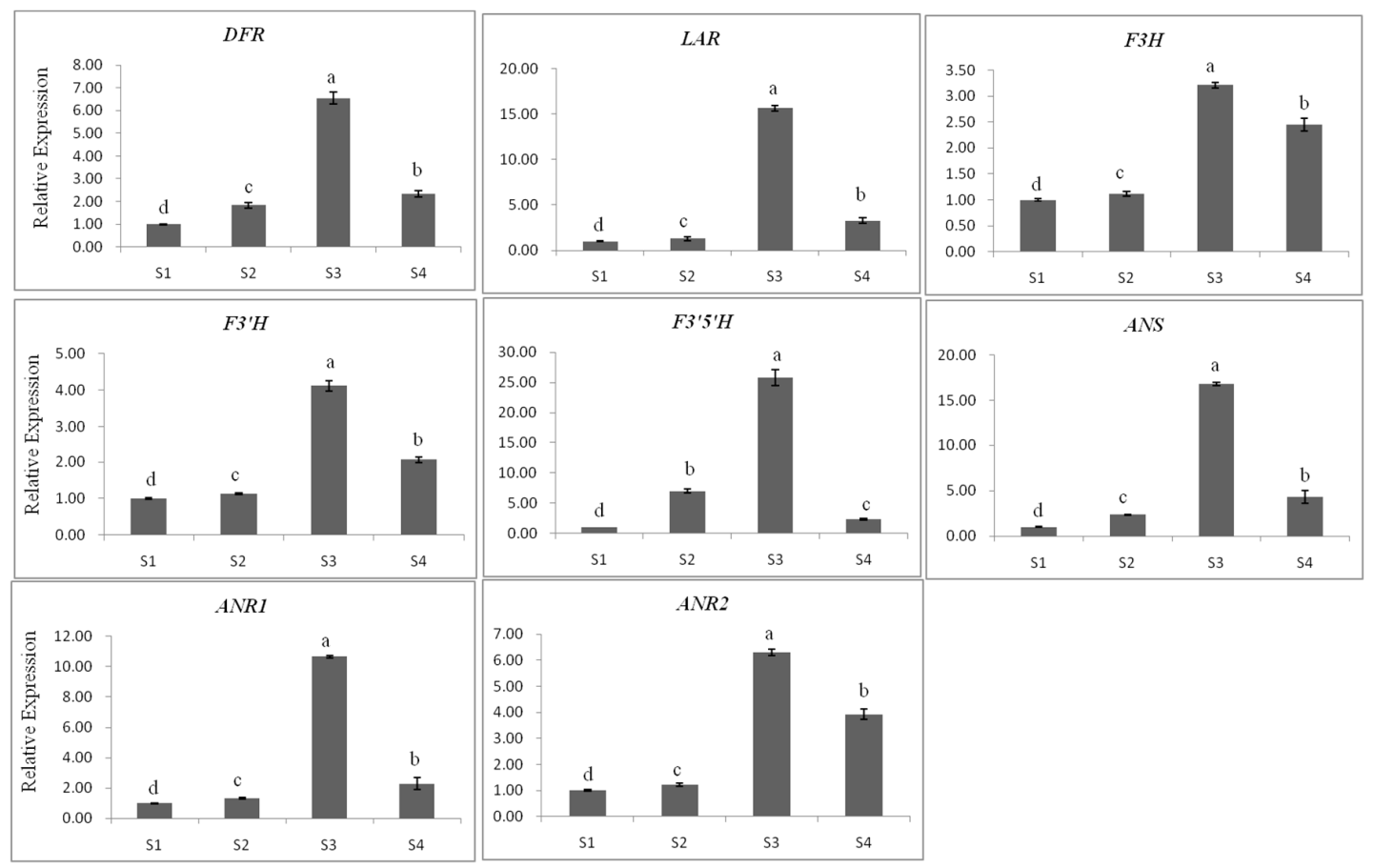

Figure 6. Expression levels of $C s F 3^{\prime} H$ \& other flavan 3-ol biosynthesis related genes for tea seedling at different stages. The data represent the mean \pm SD from three independent measurements. Means in each column for each genes labeled with the same letter are not significantly different $(p>0.05)$ based on one-way ANOVA with Duncan's multiple range test.

\subsubsection{Flavan 3-ol Accumulation in Tea Seed Germination}

The HPLC analysis demonstrated that the contents of seven typical tea flavan 3-ols in the leaves varied in different developmental stages (Figure 7). Among these flavan 3-ols, epigallocatechingallate (EGCG), which ranged from $6.89 \mathrm{mg} \cdot \mathrm{g}^{-1}$ (S4) to $11.52 \mathrm{mg} \cdot \mathrm{g}^{-1}$ (S3), was the most abundant, and catechin (C) was the least, ranging from $1.90 \mathrm{mg} \cdot \mathrm{g}^{-1}$ (S4) to $3.06 \mathrm{mg} \cdot \mathrm{g}^{-1}$ (S3). Based on the number of hydroxyl groups in the B-ring, flavan 3-ols can be classified into dihydroxylated catechins $\left(3^{\prime}, 4^{\prime}\right.$-catechins) and trihydroxylated catechins $\left(3^{\prime}, 4^{\prime}, 5^{\prime}\right.$-catechins). C, EC, ECG and CG are $3^{\prime}, 4^{\prime}$-catechins and EGC, EGCG and GCG are $3^{\prime}, 4^{\prime}, 5^{\prime}$-catechins. The concentration of $3^{\prime}, 4^{\prime}$-catechins changed from $6.23 \mathrm{mg} \cdot \mathrm{g}^{-1}$ (S4) to $11.53 \mathrm{mg} \cdot \mathrm{g}^{-1}$ (S1) and that of $3^{\prime}, 4^{\prime}, 5^{\prime}$-catechins from $10.25 \mathrm{mg} \cdot \mathrm{g}^{-1}$ (S1) to $17.63 \mathrm{mg} \cdot \mathrm{g}^{-1}$ (S3). It is obvious that the concentration of $3^{\prime}, 4^{\prime}, 5^{\prime}$-catechins were higher than that of $3^{\prime}, 4^{\prime}$-catechins in all stages, which is in agreement with previous reports [11,39]. Flavan 3-ol concentration obtained by summarizing all the individual components had a range from $17.96 \mathrm{mg} \cdot \mathrm{g}^{-1}$ (in S4) to $27.96 \mathrm{mg} \cdot \mathrm{g}^{-1}$ (in S3). During the process the changes in C, EGCG, GCG, $3^{\prime}, 4^{\prime}$-catechins, $3^{\prime}, 4^{\prime}, 5^{\prime}$-catechins and flavan 3-ols, showed similar patterns, with a gradual increase from S1 to S3, then decrease in S4. This variation trend was consistent with the expression level of the genes involved in the biosynthesis of flavan 3-ols.

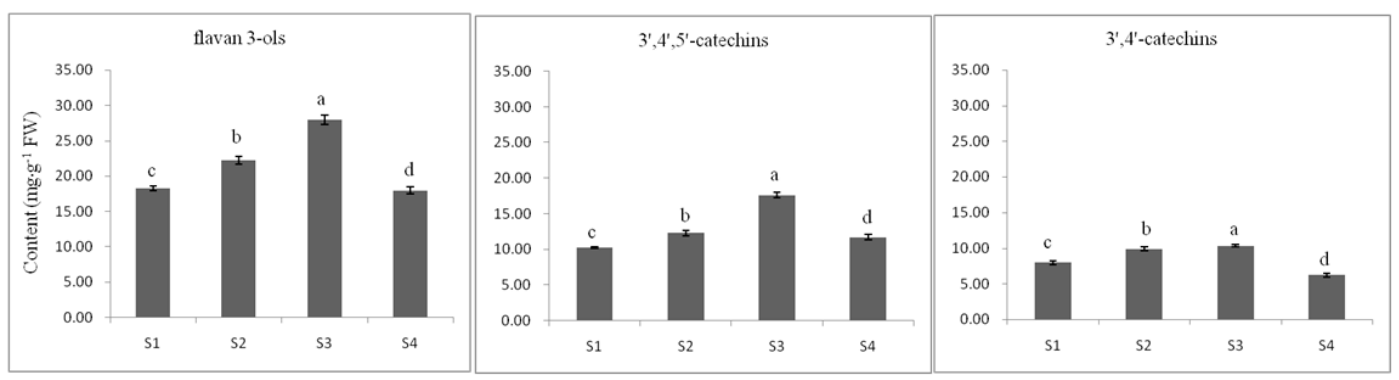

Figure 7. Cont. 


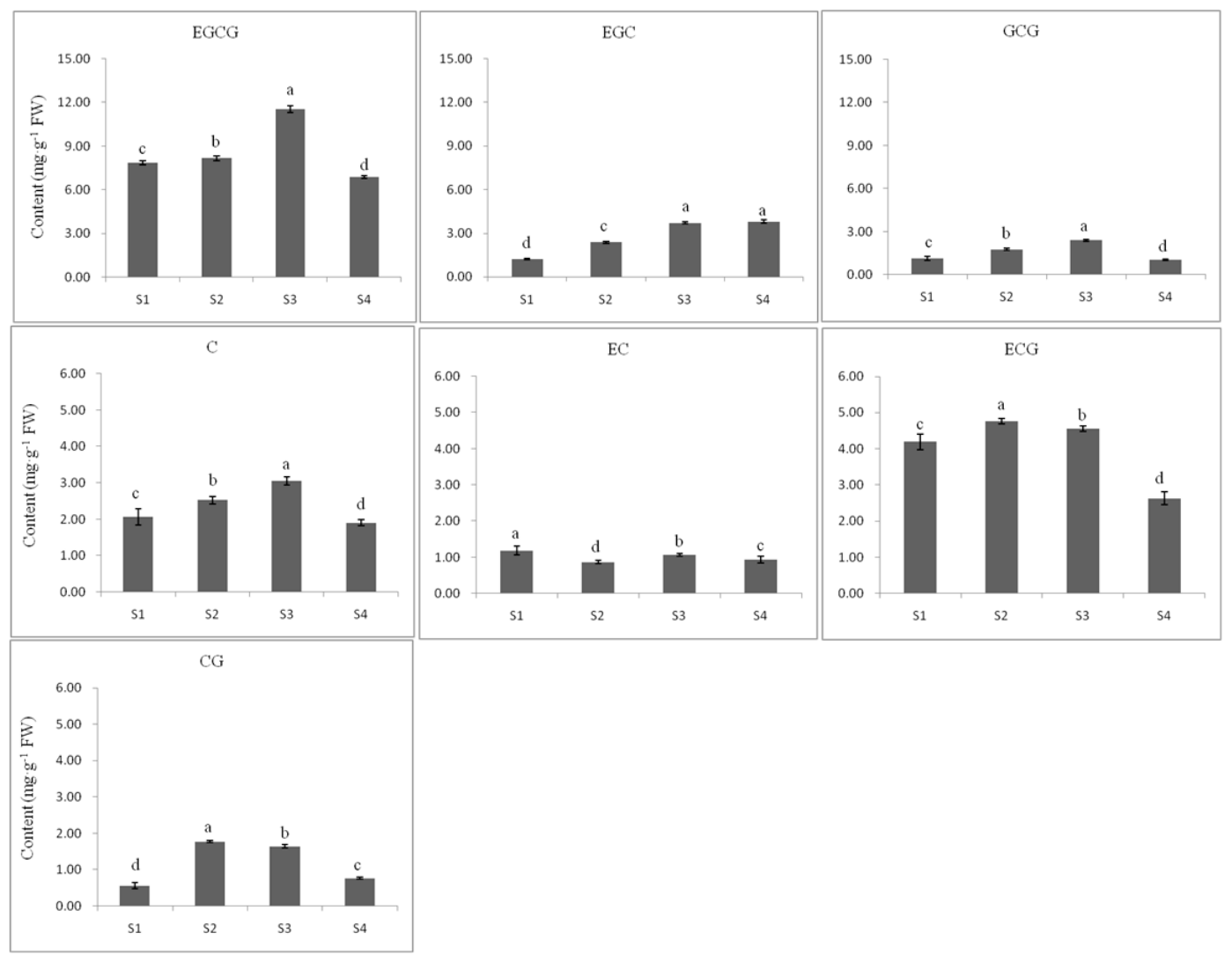

Figure 7. Content of flavan 3-ols in tea seedling at different developmental stages. The data represent the mean \pm SD from three independent measurements. Means in each column for each flavan 3-ol labeled with the same letter are not significantly different $(p>0.05)$ based on one-way ANOVA with Duncan's multiple range test.

\subsubsection{The Relationship between Gene Expression and Accumulation of Flavan 3-ols}

The relationship between the expression of genes involved in flavonoid biosynthesis and accumulation of flavan 3-ols were analyzed (Table 2). The data indicated that the correlation coefficients between the expression levels of the key genes (PAL, CHS, CHI, F3H, F3' $5^{\prime} H, D F R, A N S, L A R, A N R 1$ and ANR2) and the concentration of flavan 3-ols (or $3^{\prime}, 4^{\prime}, 5^{\prime}$-catechins) were higher than that of $3^{\prime}, 4^{\prime}$-catechins. CsF3' $H$ showed similar pattern with these investigated genes with this issue in the present study, suggesting its important role in flavonoid biosynthesis.

Table 2. The correlation coefficiency between gene expression level and flavan 3-ols.

\begin{tabular}{cccc}
\hline Correlation Coefficient & $\mathbf{3}^{\prime}, \mathbf{4}^{\prime}$-Catechins & $\mathbf{3}^{\prime}, \mathbf{4}^{\prime}, \mathbf{5}^{\prime}$-Catechins & Flavan 3-ols \\
\hline$P A L$ & 0.513 & $0.981^{*}$ & 0.885 \\
$C H S$ & 0.552 & $0.970^{*}$ & 0.893 \\
$C H I$ & 0.557 & $0.970^{*}$ & 0.895 \\
$F 3 H$ & 0.077 & 0.812 & 0.591 \\
$D F R$ & 0.526 & $0.986^{*}$ & 0.893 \\
$A N S$ & 0.508 & $0.977^{*}$ & 0.879 \\
$A N R 1$ & 0.531 & $0.971^{*}$ & 0.885 \\
$A N R 2$ & 0.166 & 0.861 & 0.661 \\
$L A R$ & 0.506 & $0.967^{*}$ & 0.872 \\
$F 3^{\prime} H$ & 0.364 & 0.941 & 0.796 \\
$F 3^{\prime} 5^{\prime} H$ & 0.723 & $0.990^{*}$ & 0.975 \\
\hline
\end{tabular}

* Significant correlation $(p<0.01)$. 


\subsection{Flavan 3-ols Accumulation and Gene Expression Response to Nitrogen Dificiency}

Seven of the typical tea flavan 3-ols were detectable in both nitrogen replete plants and nitrogen deprived plants from 0 to 12 day. The concentration of $3^{\prime}, 4^{\prime}$-catechins (C, EC, ECG and CG), $3^{\prime}, 4^{\prime}, 5^{\prime}$-catechins (EGC, EGCG and GCG) and flavan 3-ols were compared and the results are shown in Figure 8. In the nitrogen replete plants, the concentration of $3^{\prime}, 4^{\prime}$-catechins ranged from $5.51 \mathrm{mg} \cdot \mathrm{g}^{-1}$ (day 12) to $6.52 \mathrm{mg} \cdot \mathrm{g}^{-1}$ (day 4 ) and that of $3^{\prime}, 4^{\prime}, 5^{\prime}$-catechins ranged from $19.02 \mathrm{mg} \cdot \mathrm{g}^{-1}$ (day 12) to $23.74 \mathrm{mg} \cdot \mathrm{g}^{-1}$ (day 4). Flavan 3-ols concentration ranged from $24.53 \mathrm{mg} \cdot \mathrm{g}^{-1}$ (day 12 ) to $30.26 \mathrm{mg} \cdot \mathrm{g}^{-1}$ (day 4). During the process the changes in $3^{\prime}, 4^{\prime}$-catechins, $3^{\prime}, 4^{\prime}, 5^{\prime}$-catechins and flavan 3-ols, showed similar patterns, which increased from day 0 to day 4 then gradually decreased from day 4 to day 12 . However, in nitrogen deprived plants, the concentration of $3^{\prime}, 4^{\prime}$-catechins varied from $6.08 \mathrm{mg} \cdot \mathrm{g}^{-1}$ (day 0 ) to $7.31 \mathrm{mg} \cdot \mathrm{g}^{-1}$ (day 12) and that of $3^{\prime}, 4^{\prime}, 5^{\prime}$-catechins varied from $19.43 \mathrm{mg} \cdot \mathrm{g}^{-1}$ (day 8 ) to $22.41 \mathrm{mg} \cdot \mathrm{g}^{-1}$ (day 12). Flavan 3-ols concentration changed from $25.92 \mathrm{mg} \cdot \mathrm{g}^{-1}$ (day 8) to $29.71 \mathrm{mg} \cdot \mathrm{g}^{-1}$ (day 12). During nitrogen deficiency treatment the changes in $3^{\prime}, 4^{\prime}$-catechins, $3^{\prime}, 4^{\prime}, 5^{\prime}$-catechins and flavan 3-ols in the shoot tissues, increased from day 0 to day 4 then decreased from day 4 to day 8 and then increased from day 8 to day 12 . The concentration of $3^{\prime}, 4^{\prime}$-catechins, $3^{\prime}, 4^{\prime}, 5^{\prime}$-catechins and flavan 3-ols on day 12 was 1.33-, 1.18- and 1.21-fold higher, respectively, in nitrogen deprived plants than in the plants given full nutrient solution. From day 8 to day $12,3^{\prime}, 4^{\prime}$-catechins $, 3^{\prime}, 4^{\prime}, 5^{\prime}$-catechins and flavan 3-ols showed an increasing trend in response to nitrogen deprivation.

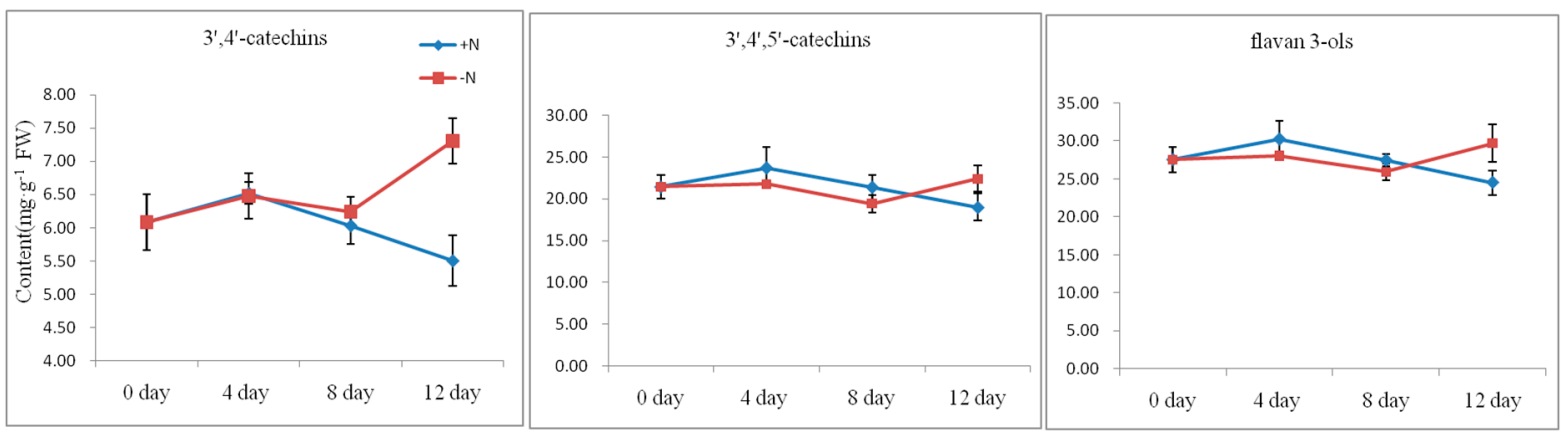

Figure 8. Content of flavan 3-ols in nitrogen deprived tea plants. The data represent the mean \pm SD from three independent measurements.

The expression level of the gene was measured by real-time PCR, using the sample harvested on day 0 as calibrator (Figure 9). In the plant receiving nitrogen, expression of the $F 3^{\prime} H$ gene and nine other key genes (except ANR1) have the same pattern, with lower expression on day 0, increased to a maximum by day 4 , and then decreased over time, which were consistent with the expression profile in developmental stages (Figure 6). Whereas the plant depleted nitrogen, the expression of all genes tested showed similar features, with low expression on day 0 , increased by day 4 and decreased by day 8 , and then increased to a maximum by day 12. The expression of $F 3^{\prime} H$ and ten other genes $(P A L$, CHS, CHI, F3H, F3'5' H, DFR, LAR, ANS, ANR1 and ANR2) on day 12 was 2.61-, 2.59-, 2.03-, 2.83-, 2.98-, 1.61-, 4.66-, 4.31-, 5.33-, 1.66- and 4.02-fold higher, respectively, in the plants deprived of nitrogen as compared to that in the plants given full nutrient solution. All genes showed a general increase in their expressions in tea plants in response to nitrogen deprivation from day 8 to day 12 (Figure 9).

The increase in flavan 3-ol biosynthesis-related genes, and the increase in flavan 3-ols content during nitrogen deficiency from day 8 to day 12 are consistent. However, these increases were lower than those in several other plants such as Arabidopsis thaliana [40,41], and tomato [42,43]. In addition, it took a longer time for tea plants to increase flavonoid synthesis and the expression level of related-genes in response to nitrogen deficiency. The reason for this needs to be further investigated in the future. 


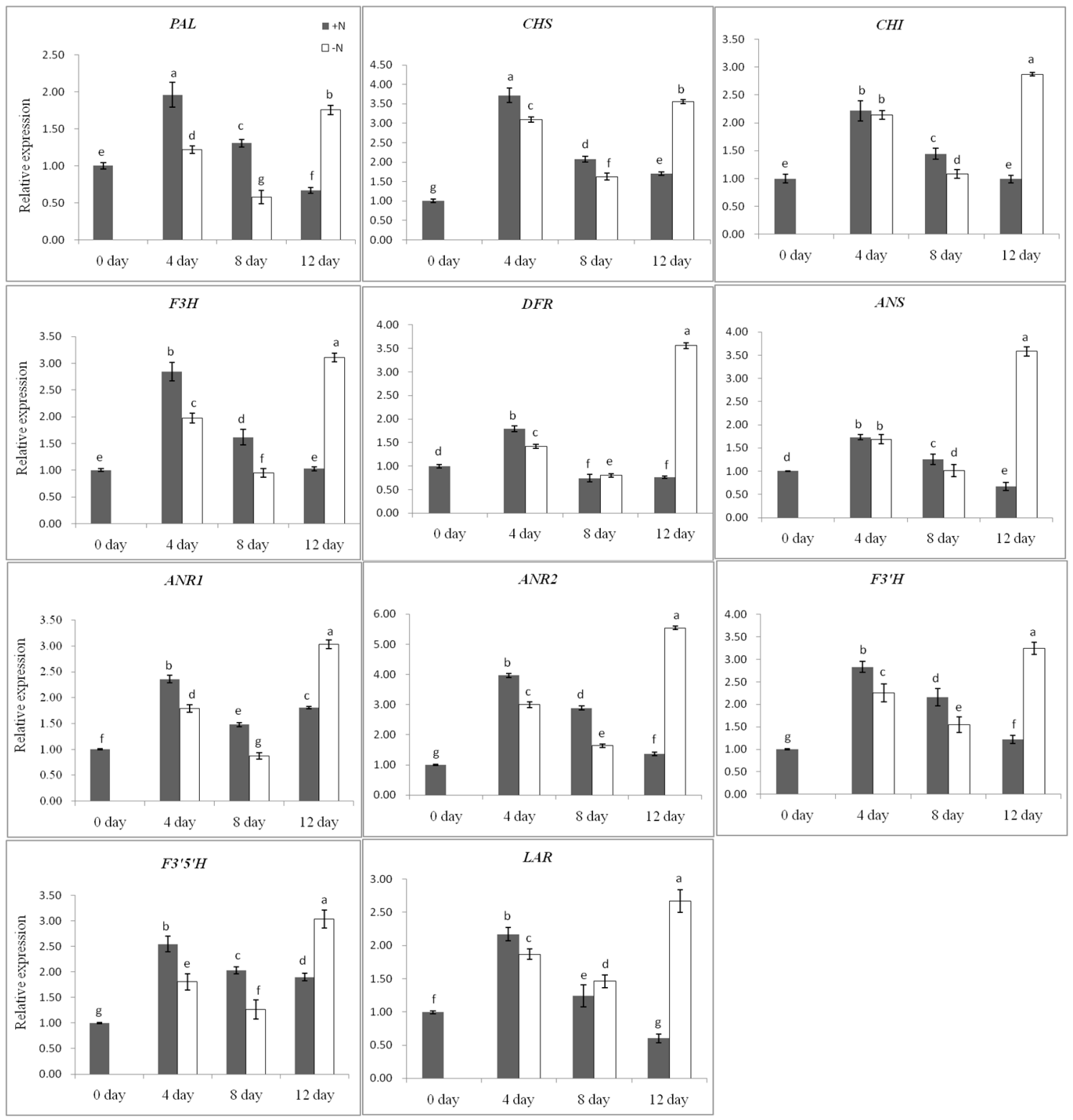

Figure 9. Expression levels of $C s F 3^{\prime} H$ and other flavan 3-ol biosynthesis related genes in nitrogen deprived tea plants. The data represents the mean \pm SD from three independent measurements. Means in each column for each genes labeled with the same letter are not significantly different $(p>0.05)$ based on one-way ANOVA with Duncan's multiple range test.

\section{Experimental Section}

\subsection{Plant Materials}

Samples of Camellia sinensis cv. Wuniuzao, were obtained from Xixiang Tea Experimental Station of Northwest A\&F University at Xixiang (Hanzhong, China), which is situated at $32^{\circ} 58^{\prime} \mathrm{N}$ and $107^{\circ} 40^{\prime} \mathrm{E}$ and $450 \mathrm{~m}$ above sea level. The new shoots (one leaf and one bud) were plucked and immediately frozen in liquid nitrogen, and stored at $-80{ }^{\circ} \mathrm{C}$ until use in the study.

To detect the expression of genes during tea seed germination, mature fruits were collected from tea plant of Camellia sinensis cv. Wuniuzao growing in Xixiang Tea Experimental Station of Northwest A\&F University. The seeds were sorted in water for 2 to $3 \mathrm{~h}$ after the fruit coat was removed. Only the seeds that sunk to the bottom of water were selected and sown in a soil mix (grass charcoal/perlite 
$(3 / 1, v / v))$ in plastic pots, which were kept at $25^{\circ} \mathrm{C}$ under a $12 / 12 \mathrm{~h}$ (day/night) photoperiod for seed germination. The light was provided by cool-fluorescent tubes at a photon flux density of $52 \mu \mathrm{mol} \cdot \mathrm{m}^{-2} \cdot \mathrm{s}^{-1}$. The shoot tops (including shoot apex and developing leaves) were collected at 20, 30, 40 and 50 days after germination respectively, immediately frozen in liquid nitrogen and stored at $-80^{\circ} \mathrm{C}$ until analysis. The frozen tissues were pulverized in liquid nitrogen. RNA and flavonoid analysis were performed with the same powder. The samples were taken from three to eight plants.

To explore the effect of nitrogen depletion on the expression of genes, one-year-old rooted cuttings of tea plant (Camellia sinensis cv. Wuniuzao) were employed as the experimental materials. After washing the roots thoroughly, the cutting plants were transplanted in plastic pots containing hydroponic culture nutrient solution [44]. The basal nutrient solution was supplied stepwise at $1 / 5$ strength of its concentration for 7 days, $1 / 2$ strength for 7 days, and full strength for the other days before treatment. The $\mathrm{pH}$ of the solution was adjusted to 4.5 every two days with $5 \mathrm{~mol} \cdot \mathrm{L}^{-1} \mathrm{H}_{2} \mathrm{SO}_{4}$. All the culture solutions were renewed once a week. During the culture of plants, forced aeration was performed. All cultures were maintained in the same conditions for seed germination described above. When the plants was putting out new shoots (one bud and two leaves), the plants were shifted to a nitrogen deprived regimen where $\left(\mathrm{NH}_{4}\right)_{2} \mathrm{SO}_{4}$ was changed to $\mathrm{K}_{2} \mathrm{SO}_{4}$ and $\mathrm{Ca}\left(\mathrm{NO}_{3}\right)_{2} \cdot 4 \mathrm{H}_{2} \mathrm{O}$ was changed to $\mathrm{CaCl}_{2} \cdot 2 \mathrm{H}_{2} \mathrm{O}$.

The roots of tea plants were washed in dilute $\mathrm{H}_{2} \mathrm{SO}_{4}(\mathrm{pH}$ 3.0) and rinsed with distilled water to remove nutrients (referred to as day 0 ). Then tea plants were divided into two groups randomly. One group was shifted to deprived nitrogen solution and another group was shifted to complete solution. Samples (one bud and two leaves) were harvested and pooled from three plants with nitrogen supply and three plants without nitrogen supply at day 4, day 8 and day 12 respectively. The tissues were harvested, frozen, stored and ground to powder for analysis as described above. The samples for RNA and flavonoid analysis were taken from the same powder.

\subsection{Isolation of the Flavonoid 3'-hydroxylase Gene}

Total RNA was extracted from the leaves of Camellia sinensis cv. Wuniuzao using RNAiso Plus Total RNA kit (TaKaRa, Japan). Single-strand cDNA was synthesized from $5 \mu \mathrm{g}$ of total RNA with an oligo(dT)17 primer using PrimeScript TM RT reagent kit (TaKaRa, Japan) according to the manufacturer's protocols. The resultant single-strand CDNA was used as the template for PCR amplification of the target cDNA with 1.5 units Phusion ${ }^{\circledR}$ High-Fidelity DNA polymerase (New England Biolabs, Boston, MA, USA) and degenerated primers (forward, CACCMGNCCNCCNAAYWSNG-GNGCC; reverse, CCNTTYGGNGCNGGNMGNMGNATHTG) designed with reference to the conserved region of $\mathrm{F}^{\prime} \mathrm{H}$ sequence from other plants. The PCR products were separated by agarose gel electrophoresis and purified with a QIAEX II Gel Extraction Kit (QIAGEN, Mansfield, MA, USA). The purified PCR fragments were then subcloned into a pENTR $^{\mathrm{TM}} \mathrm{TOPO}^{\circledR}$ vector (Invitrogen, Carlsbad, CA, USA) for sequencing.

To isolate a full-length cDNA fragment by RACE, specific primers were subsequently designed based on the core fragment of $C s F 3^{\prime} H$. The $3^{\prime}$-end and $5^{\prime}$-end of $C s F 3^{\prime} H$ cDNA were amplified with the SMART ${ }^{\mathrm{TM}}$ RACE cDNA Amplification Kit (Clontech, Mountain View, CA, USA). The $5^{\prime}$ forward primers was $5^{\prime}$ GSP (AGTCGAAAGGTTTCCTTGATGATGGC) and the $3^{\prime}$ reverse primer was $3^{\prime}$ GSP (CGGCCACCCAACTCCGGTGCCAAAC). $5^{\prime}$ and $3^{\prime}$ RACE-PCR techniques were performed, using these gene specific primers and UPM (Universal Primer a mix, provided by the kit). The thermal cycling conditions were $94{ }^{\circ} \mathrm{C}$ for $5 \mathrm{~min}$; followed by 35 cycles of $95^{\circ} \mathrm{C}$ for $30 \mathrm{~s}, 60^{\circ} \mathrm{C}$ for $30 \mathrm{~s}$, and $72{ }^{\circ} \mathrm{C}$ for $1 \mathrm{~min}$; and a final elongation step at $72^{\circ} \mathrm{C}$ for $10 \mathrm{~min}$. The purified $3^{\prime}$-RACE and $5^{\prime}$-RACE products were subcloned into $\mathrm{PMD} 18$-T vectors for sequencing.

The full length cDNA sequence of flavonoid 3'-hydroxylase was analyzed with SeqMan program in DNAStar 7.1 (DNASTAR Inc., Madison, WI, USA). The ORF finder programmer at the NCBI website was used to search the open reading frames in the F $3^{\prime} H$ nucleotide sequences. Primers $C S F 3^{\prime} H$ ORF forward (CACCATGACTTCCTTAGCTTTTGTTC) and $C_{s} F 3^{\prime} H$ ORF reverse (TTAGGCCCGATACACATGGGGTG) were used to amplify the ORF of $C_{S} F 3^{\prime} H$ with Phusion ${ }^{\circledR}$ High-Fidelity DNA polymerase. PCR program 
was as follows: $98{ }^{\circ} \mathrm{C}$ for $3 \mathrm{~min}$; followed by 35 cycles of $98{ }^{\circ} \mathrm{C}$ for $20 \mathrm{~s}, 58{ }^{\circ} \mathrm{C}$ for $30 \mathrm{~s}$, and $68{ }^{\circ} \mathrm{C}$ for $1 \mathrm{~min}$; and a final elongation step at $68^{\circ} \mathrm{C}$ for $10 \mathrm{~min}$ before cooling to $4{ }^{\circ} \mathrm{C}$. The product was ligated into a pENTR $^{\text {TM }}$ TOPO $^{\circledR}$ vector (Invitrogen, Carlsbad, CA, USA).

\subsection{Bioinformatic Analysis}

According to the open reading frames, the theoretical molecular weight and isoelectronic point of $\mathrm{CsF}^{\prime} \mathrm{H}$ were calculated with ExPASy Compute PI/MW tool. Multiple alignments of protein sequences were performed by the Clustal W. The phylogenetic tree was constructed with the MEGA v5.2 software [45]. In MEGA, distance matrices were generated by the pairwise deletion option with the Poisson correction amino acid matrix. One thursand bootstrap replicates were made and trees were generated using neighbor-joining (NJ) method for each replicate. Percentage of replicates supporting each branch was given next to the nodes.

\subsection{Yeast Expression and Microsome Preparation}

The $\mathrm{CsF}^{\prime} \mathrm{H}$ ORF was cloned into the destination vector pYES-dest52 from the entry vector pENTR-CsF3'H using Gateway LR Clonase enzyme (Invitrogen, Carlsbad, CA, USA). The obtained pYES-dest52-CsF3'H was introduced into Saccharomyces cerevisiae WAT11 with a transformatin kit (Frozon-EZ yeast Transformation II, Zymo Research, Irvine, CA, USA). Meanwhile, the empty vector pYES-dest52 was transformed as control.

A single colony from a SD-U medium plate was inoculated in $50 \mathrm{~mL}$ SD-U liquid medium containing $20 \mathrm{~g} \cdot \mathrm{L}^{-1}$ glucose, and the yeast cells were grown at $30{ }^{\circ} \mathrm{C}$ for $12 \mathrm{~h}$. The cells were spun down $(1500 \times g, 5 \mathrm{~min})$ and resuspended in SD-U medium containing $20 \mathrm{~g} \cdot \mathrm{L}^{-1}$ galactose, and the resuspension was diluted to $\mathrm{OD}_{600}$ to 0.4 for substrate specificity assessment at $16{ }^{\circ} \mathrm{C}$ for $12 \mathrm{~h}$. Naringenin, dihydrokaempferol and kaempferol solutions were fed into the culture to a final concentration of $5 \mathrm{mM}$, respectively. The reactions were stopped by sonication for $15 \mathrm{~min}$ after $12 \mathrm{~h}$ incubation. The products from each reaction were extracted with $10 \mathrm{~mL}$ ethyl acetate for three times, and organic extracts were pooled, evaporated and redissolved in $15 \mathrm{~mL}$ methanol for HPLC analysis.

For microsome induction, yeast cells were firstly propagated in SD-U liquid medium containing $20 \mathrm{~g} \cdot \mathrm{L}^{-1}$ glucose, then spun down $(1500 \times g, 5 \mathrm{~min})$ and resuspended in SD-U medium containing $20 \mathrm{~g} \cdot \mathrm{L}^{-1}$ galactose diluting the $\mathrm{OD}_{600}$ to 0.4 . After induction at $16^{\circ} \mathrm{C}$ for $24 \mathrm{~h}$, the yeast microsomal fraction was prepared with $\mathrm{MgCl}_{2}$ according to Olsen et al. [16]. The resultant microsome was dissolved in pre-cooled 1.0 to $1.5 \mathrm{~mL} \mathrm{TEG} \mathrm{(30 \%} \mathrm{glycerol} \mathrm{in} 50 \mathrm{mM}$ Tris- $\mathrm{HCl}$ with $1 \mathrm{mM}$ EDTA) on ice. Protein concentrations of enzyme extract were spectrometrically determined using Coomassie Brilliant Blue G-250.

\subsection{Enzyme Assays}

As potential substrates fo $\mathrm{CsF}^{\prime} \mathrm{H}$, naringenin, dihydrokaempferol and kaempferol were tested with microsomes prepared from yeast pYES-dest52-CsF3' $H$ transformants. The reaction solution contains $100 \mathrm{mM}$ sodium phosphate buffer, pH 7.0 with $1.0 \mathrm{mM}$ NADPH. The reaction was started by the addition of microsomes after the assay mixture was equilibrated for $15 \mathrm{~min}$ at $30{ }^{\circ} \mathrm{C}$. The concentration of substrate in the assays was adjusted in the range of 1 to $300 \mu \mathrm{M}$. Total volume of the reaction system was $200 \mu \mathrm{L}$. After $30 \mathrm{~min}$ incubation the reaction was terminated by adding ethyl acetate. The products in each reaction were extracted and analyzed as described above. To validate that $\mathrm{CsF3}^{\prime} \mathrm{H}$ catalyzed the hydroxylations, control assays were run with microsomes prepared from WAT11 transformed with the pYES-dest52 vector without CsF3'H insertions.

\subsection{HPLC Analysis}

\subsubsection{Flavonoid Standards}

$( \pm)$-Naringenin, $( \pm)$-eridodictyol, $( \pm)$-dihydrokaempferol, dihydroquercetin, kaempferol and quercetin were purchased from Sigma-Aldrich (USA). (+)-Catechin, (-)-epicatechin, 
(-)-epigallocatechin, (+)-gallocatechin, (-)-epicatechin 3-O-gallate and (-)-epigallocatechin 3-O-gallate were purchased from Shanghai RongHe Phar-maceutical Co. (Shanghai, China).

\subsubsection{Analysis of Enzyme Substrates and Products}

The flavonoids were analyzed with a HPLC system (LC 20AD, Shimadzu Corporation, Japan) equipped with a Wondasil C18 column (Gl Sciences Inc., Torrance, CA, USA) and a diode array detector (SPD M20A, Shimadzu Corporation). The HPLC conditions were as follows: $10 \%-40 \%$ for $10 \mathrm{~min}, 40 \%-60 \%$ for $5 \mathrm{~min}$ and $60 \%-10 \%$ for $2 \mathrm{~min}$ at a flow rate of $1.0 \mathrm{~mL} \cdot \mathrm{min}^{-1}$ (the percentage represents the fraction of acetonitrile in the solution). The detection wavelength was set $290 \mathrm{~nm}$. Injection volume was $10 \mu \mathrm{L}$ and the separation temperature was set at $25^{\circ} \mathrm{C}$. Flavonoids generated from enzyme reactions were identified according to the retention time, UV-absorbance spectrum, and co-chromatography with authentic chemicals.

\subsubsection{Analysis of Flavan 3-ols in Leaves}

The samples for analysis of flavan 3-ols were prepared as follows: $100 \mathrm{mg}$ fresh leaves was grounded in liquid nitrogen and extracted with $1 \mathrm{~mL} \mathrm{50 \%} \mathrm{methanol} \mathrm{by} \mathrm{sonication} \mathrm{at} \mathrm{room} \mathrm{temperature}$ for $10 \mathrm{~min}$. The mixture was centrifuged at $4000 \times \mathrm{g}$ for $15 \mathrm{~min}$ and the resultant supernatant and residues were separated. The residues were re-extracted twice as above. All the supernatants were pooled and filtered through a $0.22 \mu \mathrm{m}$ membrane for HPLC analysis.

The HPLC system and column were as described as above. The mobile phase used has $2 \%$ acetic acid in water (A) and acetonitrile (B), respectively. The elution gradient increased linearly from $6.5 \%$ to $25 \% \mathrm{~B}$ at $16 \mathrm{~min}$, reduced back to $6.5 \% \mathrm{~B}$ at $25 \mathrm{~min}$ with a flow rate of $1.0 \mathrm{~mL} \cdot \mathrm{min}^{-1}$. Samples injection amount was $10 \mu \mathrm{L}$ and the separation temperature was maintained at $30^{\circ} \mathrm{C}$. The detection wavelength was set $280 \mathrm{~nm}$. One biological sample pooled from three individual plants was analyzed. Three analytical replicates were carried out for each sample.

\subsection{Expression of Genes Related to Flavan 3-ol Biosynthesis by Real-Time PCR}

Total RNA extraction and the first strand cDNA synthesis were carried out as described above. Real-time PCR reactions were assayed with an iQ5 Real-Time PCR System (Bio-Rad, Hercules, CA, USA) using SYBR ${ }^{\circledR}$ Premix Ex Taq ${ }^{\mathrm{TM}}$ II (TaKaRa, Bio Inc., China) for detection. The PCR mixture contained $2.0 \mu \mathrm{L}$ diluted cDNA (50 ng. $\left.\mu \mathrm{L}^{-1}\right), 10 \mu \mathrm{L} \mathrm{SYBR}^{\circledR}$ Premix Ex Taq ${ }^{\mathrm{TM}} \mathrm{II}, 0.8 \mu \mathrm{L}$ of forward and reverse primers $\left(10 \mu \mathrm{mol} \cdot \mathrm{L}^{-1}\right)$ in a final volume of $20 \mu \mathrm{L}$. The amplification was carried out with the following cycling parameters: $95^{\circ} \mathrm{C}$ for $2 \mathrm{~min}$, followed by 40 cycles at $95^{\circ} \mathrm{C}$ for $30 \mathrm{~s}, 52^{\circ} \mathrm{C}$ for $30 \mathrm{~s}$, and $72{ }^{\circ} \mathrm{C}$ for $30 \mathrm{~s}$. The primers for Real-Time RT-PCR are listed in Table 3. Data are expressed as mean value of three replicates, normalized against the expression levels of $\beta$-actin (HQ420251.1). The relative expression was calculated by Pfaffl's method [46].

Table 3. Primers for Real time PCR.

\begin{tabular}{|c|c|c|c|c|}
\hline Gene & Accession No. & Forward Primer $\left(5^{\prime}-3^{\prime}\right)$ & Reverse Primer $\left(5^{\prime}-3^{\prime}\right)$ & $\begin{array}{c}\text { Product } \\
\text { Length (bp) }\end{array}$ \\
\hline$P A L$ & D26596 & TCCAATTCCTTGCCAATCC & AACTGCCTCGGCTGTCTTTC & 106 \\
\hline CHS & AY169403 & ACAAAGGCAATCAAAGAATGG & ATGGGCGAAGACCGAGTAG & 124 \\
\hline $\mathrm{CHI}$ & DQ904329 & TGAGACTGAACCCAAGACCG & TAGATTTTGATGCCGATGCC & 114 \\
\hline $\mathrm{F3H}$ & AY641730 & TACСАТСАСССТGСТССТСС & CATTCTTGAACСТСССАTTGC & 153 \\
\hline$F 3^{\prime} H$ & KT180309 & TCGACCAGAACGATTCCTACC & ACTGGACCATACGCAACCCTA & 134 \\
\hline$F 3^{\prime} 5^{\prime} H$ & DQ194358 & TCTCAATCTTCCCAGAGTCGC & CAGTCTTCGCATTCTTTCCAC & 173 \\
\hline DFR & AB018685 & АTTCССАССАAGССТАATCAC & CCTGAGGACGCTCATACAAGA & 137 \\
\hline ANS & AY830416 & TTCAAGGGTATGGGAGCAAA & TGCAGGAATGTAGTCGGTTG & 139 \\
\hline$L A R$ & GU992401 & AACTCACCCTAGTCCATGCCA & CACCСTCСTCTTTTCGTTGTA & 134 \\
\hline ANR1 & GU992402 & CATAGCCGGTTGTGACCTTG & TGACACGTTTAACCGTTCCTG & 147 \\
\hline ANR2 & GU992400 & CGAGACCCAGGCAATCAGA & ACCAGGTCACAACCCGCTA & 131 \\
\hline$\beta$-actin & HQ420251.1 & GCCATCTTTG ATTGGAATGG & GGTGCCACAACCTTGATCTT & 175 \\
\hline
\end{tabular}




\section{Conclusions}

The $C_{s} F 3^{\prime} H$ gene was cloned and functionally characterized in our study. Bioinformatic analysis suggested that the $C s F 3^{\prime} H$ was highly homologous with the characterized $F 3^{\prime} H s$ from other plant species. Heterologous expression of $\mathrm{CsF}^{\prime} \mathrm{H}$ in yeast demonstrated that $\mathrm{CsF}^{\prime} \mathrm{H}$ accepted naringenin, dihydrokaempferol and kaempferol as substrates, among which naringenin was shown to be the optimal substrate. During tea seed germination, the expression levels of $C_{s} F 3^{\prime} H$ correlated positively with $3^{\prime}, 4^{\prime}$-catechins, $3^{\prime}, 4^{\prime}, 5^{\prime}$-catechins and flavan 3-ol accumulation pattern in leaves. Expression of $\mathrm{CsF}^{\prime} \mathrm{H}$ and all other tested genes in the flavonoid biosynthetic pathway increased in response to nitrogen deprivation, which were consistent with a corresponding elevation of $3^{\prime}, 4^{\prime}$-catechins, $3^{\prime}, 4^{\prime}, 5^{\prime}$-catechins and flavan 3 -ols content. These results strongly suggest the importance of our cloned $\mathrm{CsF}^{\prime} H$ in the accumulation of the flavonoids in the tea leaves.

Supplementary Materials: Supplementary materials can be found at http://www.mdpi.com/1422-0067/17/2/261/s1.

Acknowledgments: The following organizations are acknowledged for their financial support: Modern Agricultural Technology Project of China (No. CARS-23), Station Scientific and Technological Innovation and Transformation Project of Northwest A\&F University (No. NYY2013-23).

Author Contributions: Conceived and designed the experiments: Tian-Shan Zhou, Ya-Jun Yang, Oliver Yu. Performed the experiments: Tian-Shan Zhou, Rui Zhou, Yao Xiao. Analyzed the data: Tian-Shan Zhou, You-Ben Yu, Dong-Hua Li. Contributed reagents/materials/analysis tools: Oliver Yu, Bin Xiao. Wrote the paper: Tian-Shan Zhou.

Conflicts of Interest: The authors declare no conflict of interest.

\section{References}

1. Lin, Y.S.; Tsai, Y.J.; Tsay, J.S.; Lin, J.K. Factors affecting the levels of tea polyphenols and caffeine in tea leaves. J. Agric. Food Chem. 2003, 51, 1864-1873. [CrossRef] [PubMed]

2. Bhattacharya, U.; Adak, S.; Majumder, N.S.; Bera, B.; Giri, A.K. Antimutagenic and anticancer activity of Darjeeling tea in multiple test systems. BMC Complement. Altern. Med. 2014, 14, 327. [CrossRef] [PubMed]

3. Tijburg, L.B.M.; Mattern, T.; Folts, J.D.; Weisgerber, U.M.; Katan, M.B. Tea flavonoids and cardiovascular diseases: A review. Crit. Rev. Food Sci. 1997, 37, 771-785. [CrossRef] [PubMed]

4. Fukai, K.; Ishigami, T.; Hara, Y. Antibacterial activity of tea polyphenols against phytopathogenic bacteria. Agric. Biol. Chem. 1991, 55, 1895-1897. [CrossRef]

5. Cavet, M.E.; Harrington, K.L.; Vollmer, T.R.; Ward, K.W.; Zhang, J.Z. Anti-inflammatory and anti-oxidative effects of the green tea polyphenol epigallocatechin gallate in human corneal epithelial cells. Mol. Vis. 2011, 17, 533-542. [PubMed]

6. Matsuo, N.; Yamada, K.; Shoji, K.; Mori, M.; Sugano, M. Effect of tea polyphenols on histamine release from rat basophilic leukemia (RBL-2H3) cells: The structure-inhibitory activity relationship. Allergy Eur. J. Allergy Clin. Immunol. 1997, 52, 58-64. [CrossRef]

7. Dixon, R.A.; Pasinetti, G.M. Flavonoids and isoflavonoids: From plant biology to agriculture and neuroscience. Plant Physiol. 2010, 154, 453-457. [CrossRef] [PubMed]

8. Soobrattee, M.A.; Neergheen, V.S.; Luximon, R.A.; Aruoma, O.I.; Bahorun, T. Phenolics as potential antioxidant therapeutic agents: Mechanism and actions. Mutat. Res. Fund Mol. M 2005, 579, 200-213. [CrossRef] [PubMed]

9. Winkel-Shirley, B. Flavonoid biosynthesis: A colorful model for genetics, biochemistry, cell biology, and biotechnology. Plant Physiol. 2001, 126, 485-493. [CrossRef] [PubMed]

10. Seitz, C.; Eder, C.; Deiml, B.; Kellner, S.; Martens, S.; Forkmann, G. Cloning, functional identification and sequence analysis of flavonoid $3^{\prime}$-hydroxylase and flavonoid $3^{\prime}, 5^{\prime}$-hydroxylase cDNAs reveals independent evolution of flavonoid $3^{\prime}, 5^{\prime}$-hydroxylase in the Asteraceae family. Plant Mol. Biol. 2006, 61, 365-381. [CrossRef] [PubMed]

11. Ashihara, H.; Deng, W.W.; Mullen, W.; Crozier, A. Distribution and biosynthesis of flavan-3-ols in Camellia sinensis seedlings and expression of genes encoding biosynthetic enzymes. Phytochemistry 2010, 71, 559-566. [CrossRef] [PubMed]

12. Wang, Y.S.; Xu, Y.J.; Gao, L.P.; Yu, O.; Wang, X.Z.; He, X.J.; Jiang, X.L.; Liu, Y.J.; Xia, T. Functional analysis of flavonoid $3^{\prime}, 5^{\prime}$-hydroxylase from Tea plant (Camellia sinensis): Critical role in the accumulation of catechins. BMC Plant Biol. 2014, 14, 374. [CrossRef] [PubMed] 
13. Wei, K.; Wang, L.Y.; Zhou, J.; He, W.; Zeng, J.M.; Jiang, Y.W.; Cheng, H. Catechin contents in tea (Camellia sinensis) as affected by cultivar and environment and their relation to chlorophyll contents. Food Chem. 2011, 125, 44-48. [CrossRef]

14. Jin, J.Q.; Ma, J.Q.; Ma, C.L.; Yao, M.Z.; Chen, L. Determination of catechin content in representative Chinese tea germplasms. J. Agric. Food Chem. 2014, 62, 9436-9441. [CrossRef] [PubMed]

15. Owuor, P.O.; Obanda, M. The use of green tea (Camellia sinensis) leaf flavan-3-ol composition in predicting plain black tea quality potential. Food Chem. 2007, 100, 873-884. [CrossRef]

16. Olsen, K.M.; Hehn, A.; Jugde, H.; Slimestad, R.; Larbat, R.; Bourgaud, F.; Lillo, C. Identification and characterisation of CYP75A31, a new flavonoid 3',5'-hydroxylase, isolated from Solanum. lycopersicum. BMC Plant Biol. 2010, 10, 21. [CrossRef] [PubMed]

17. Brugliera, F.; Barri-Rewell, G.; Holton, T.A.; Mason, J.G. Isolation and characterization of a flavonoid 3'-hydroxylase cDNA clone corresponding to the Ht1 locus of Petunia hybrida. Plant J. 1999, 19, 441-451. [CrossRef] [PubMed]

18. Schoenbohm, C.; Martens, S.; Eder, C.; Forkmann, G.; Weisshaar, B. Identification of the Arabidopsis thaliana flavonoid 3'-hydroxylase gene and functional expression of the encoded P450 enzyme. Biol. Chem. 2000, 381, 749-753. [CrossRef] [PubMed]

19. Werck-Reichhart, D.; Bak, S.; Paquette, S. Cytochromes P450. The Arabidopsis Book; Somerville, C.R., Meyerowitz, E.M., Eds.; NCBI: Rockville, MD, USA, 2002.

20. Wei, K.; Wang, L.Y.; Zhang, C.C.; Wu, L.Y.; Li, H.L.; Zhang, F.; Cheng, H. Transcriptome analysis reveals key flavonoid $3^{\prime}$-hydroxylase and flavonoid $3^{\prime}, 5^{\prime}$-hydroxylase genes in affecting the ratio of dihydroxylated to trihydroxylated catechins in Camellia sinensis. PLoS ONE 2015. [CrossRef] [PubMed]

21. Lillo, C.; Lea, U.S.; Ruoff, P. Nutrient depletion as a key factor for manipulating gene expression and product formation in different branches of the flavonoid pathway. Plant Cell Environ. 2008, 31, 587-601. [CrossRef] [PubMed]

22. Olsen, K.M.; Slimestad, R.; Lea, U.S.; Brede, C.; Løvdal, T.; Ruoff, P.; Verheul, M.; Lillo, C. Temperature and nitrogen effects on regulators and products of the flavonoid pathway: Experimental and kinetic model studies. Plant Cell Environ. 2009, 32, 286-299. [CrossRef] [PubMed]

23. Yamazaki, S.; Sato, K.; Suhara, K.; Sakaguchi, M.; Mihara, K.; Omura, T. Importance of the proline-rich region following signal-anchor sequence in the formation of correct conformation of microsomal cytochrome P450s. J. Biochem. 1993, 114, 652-657. [PubMed]

24. Murakami, K.; Mihara, K.; Omura, T. The transmembrane region of microsomal cytochrome P450 identified as the endoplasmic reticulum retention signal. J. Biochem. 1994, 116, 164-175. [PubMed]

25. Werck-Reichhart, D.; Feyereisen, R. Cytochromes P450: A success story. Genome Biol. 2000, 1, 3003.1-3003.9. [CrossRef] [PubMed]

26. Chapple, C. Molecular-genetic analysis of plant cytochrome P450-dependent monooxygenases. Annu. Rev. Plant Physiol. Plant Mol. Biol. 1998, 49, 311-343. [CrossRef] [PubMed]

27. Hasemann, C.A.; Kurumbail, R.G.; Boddupalli, S.S.; Peterson, J.A.; Deisenhofer, J. Structure and function of cytochrome P450: A comparative analysis of three crystal structures. Structure 1995, 3, 41-62. [CrossRef]

28. Boddu, J.; Svabek, C.; Sekhon, R.; Gevens, A.; Nicholson, R.L.; Jones, A.D.; Pedersen, J.F.; Gustine, D.L.; Chopra, S. Expression of a putative flavonoid $3^{\prime}$-hydroxylase in sorghum mesocotyls synthesizing 3-deoxyanthocyanidin phytoalexins. Physiol. Mol. Plant Pathol. 2004, 65, 101-113. [CrossRef]

29. Han, Y.P.; Vimolmangkang, S.; Soria-Guerra, R.E.; Rosales-Mendoza, S.; Zheng, D.M.; Lygin, A.V.; Korban, S.S. Ectopic expression of apple $\mathrm{F}^{\prime} \mathrm{H}$ genes contribute to anthocyanin accumulation in the Arabidopsis tt7 mutant grown under nitrogen stress. Plant Physiol. 2010, 153, 806-820. [CrossRef] [PubMed]

30. Takatori, Y.; Shimizu, K.; Ogata, J.; Endo, H.; Ishimaru, K.; Okamoto, S.; Hashimoto, F. Cloning of the flavonoid 3'-hydroxylase gene of Eustoma grandiflorum (Raf.) Shinn. ( $E g F 3^{\prime} H$ ) and complementation of an F3'H-deficient Mutant of Ipomoea nil (L.) Roth. by heterologous expression of EgF3'H. Horic. J. 2015, 84, 131-139. [CrossRef]

31. Zhou, W.; Gong, Y.F.; Lu, X.; Huang, C.T.; Gao, F. Molecular cloning and characterization of a flavonoid 3'-hydroxylase gene from purple-fleshed sweet potato (Ipomoea batatas). Mol. Biol. Rep. 2012, 39, $295-302$. [CrossRef] [PubMed]

32. Pompon, D.; Louerat, B.; Bronine, A.; Urban, P. Yeast expression of animal and plant P450s in optimized redox environments. Methods Enzymol. 1996, 272, 51-64. [PubMed] 
33. Teoh, K.H.; Polichuk, D.R.; Reed, D.W.; Nowak, G.; Covello, P.S. Artemisia annua L. (Asteraceae) trichome-specific cDNAs reveal CYP71AV1, a cytochrome $\mathrm{P} 450$ with a key role in the biosynthesis of the antimalarial sesquiterpene lactone artemisinin. FEBS Lett. 2006, 580, 1411-1416. [CrossRef] [PubMed]

34. Ueyama, Y.; Suzuki, K.; Fukuchi-Mizutani, F.; Fukui, Y.; Miyazaki, K.; Ohkawa, H.; Kusumi, T.; Tanaka, Y. Molecular and biochemical characterization of torenia flavonoid $3^{\prime}$-hydroxylase and flavone synthase and modification of flower color by modulating the expression of these genes. Plant Sci. 2002, 163, 253-263. [CrossRef]

35. Doostdar, H.; Shapiro, J.P.; Niedz, R.; Burke, M.D.; McCollum, T.G.; McDonald, R.E.; Mayer, R.T. A cytochrome P450 mediated naringenin 3'-hydroxylase from sweet orange cell cultures. Plant Cell Physiol. 1995, 36, 69-77.

36. Schwinn, K.; Miosic, S.; Davies, K.; Thill, J.; Gotame, T.P.; Stich, K.; Halbwirth, H. The B-ring hydroxylation pattern of anthocyanins can be determined through activity of the flavonoid $3^{\prime}$-hydroxylase on leucoanthocyanidins. Planta 2014, 240, 1003-1010. [CrossRef] [PubMed]

37. Fritsch, H.; Grisebach, H. Biosynthesis of cyanidin in cell cultures of Haplopappus gracilis. Phytochemistry 1975, 14, 2437-2442. [CrossRef]

38. Hagmann, M.L.; Heller, W.; Grisebach, H. Induction and characterization of a microsomal Flavonoid 3'-hydroxylase from parsley cell cultures. FEBS J. 1983, 134, 547-554. [CrossRef]

39. Xiong, L.G.; Li, J.; Li, Y.H.; Yuan, L.; Liu, S.Q.; Huang, J.A.; Liu, Z.H. Dynamic changes in catechin levels and catechin biosynthesis-related gene expression in albino tea plants (Camellia sinensis L). Plant Physiol. Biochem. 2013, 71, 132-143. [CrossRef] [PubMed]

40. Løvdal, T.; Olsen, K.M.; Slimestad, R.; Verheul, M.; Lillo, C. Synergetic effects of nitrogen depletion, temperature, and light on the content of phenolic compounds and gene expression in leaves of tomato. Phytochemistry 2010, 71, 605-613. [CrossRef] [PubMed]

41. Larbat, R.; Olsen, K.M.; Slimestad, R.; Løvdal, T.; Bénard, C.; Verheul, M.; Bourgaud, F.; Robin, C.; Lillo, C. Influence of repeated short-term nitrogen limitations on leaf phenolics metabolism in tomato. Phytochemistry 2012, 77, 119-128. [CrossRef] [PubMed]

42. Nemie-Feyissa, D.; Olafsdottir, S.M.; Heidari, B.; Lillo, C. Nitrogen depletion and small R3-MYB transcription factors affecting anthocyanin accumulation in Arabidopsis leaves. Phytochemistry 2014, 98, 34-40. [CrossRef] [PubMed]

43. Olsen, K.M.; Lea, U.S.; Slimestad, R.; Verheul, M.; Lillo, C. Differential expression of four Arabidopsis PAL genes; PAL1 and PAL2 have functional specialization in abiotic environmental-triggered flavonoid synthesis. J. Plant Physiol. 2008, 165, 1491-1499. [CrossRef] [PubMed]

44. Konishi, S.; Miyamoto, S.; Taki, T. Stimulatory effects of aluminum on tea plants grown under low and high phosphorus supply. Soil Sci. Plant Nutr. 1985, 31, 361-368. [CrossRef]

45. Tamura, K.; Peterson, D.; Peterson, N.; Stecher, G.; Nei, M.; Kumar, S. Mega 5: Molecular evolutinary genetics analysis using maximum likelihood, evolutionary distance, and maximum parsimony methods. Mol. Biol. Evol. 2011, 28, 2731-2739. [CrossRef] [PubMed]

46. Pfaffl, M.W. A new mathematical model for relative quantification in real-time RT-PCR. Nucleic Acids Res. 2001, 29, 2002-2007. [CrossRef]

(C) 2016 by the authors; licensee MDPI, Basel, Switzerland. This article is an open access article distributed under the terms and conditions of the Creative Commons by Attribution (CC-BY) license (http://creativecommons.org/licenses/by/4.0/). 